21_Linguaculture 2, 2019

\title{
C.S. LEWIS'S TRILEMMA SEEN THROUGH MUSLIM EYES
}

\author{
Christian TĂMAȘ \\ Independent Scholar
}

\begin{abstract}
Beyond his apologetic works about Jesus Christ and the Christian faith, C.S. Lewis polarized the religious and non-religious world with his famous Trilemma expressing his opinion on the nature and identity of Christ. While for the Christians and atheists C.S. Lewis's Trilemma is still a matter of rather harsh debate, for the Muslims it represents a matter of lesser importance. Some of those acquainted with C.S. Lewis's ideas approached it with caution taking into account the Qur'anic statements about the revelations previously "descended” upon man, which generally prevent the Muslims from commenting or interpreting the other monotheistic scriptures. Thus, many Muslim scholars consider C.S. Lewis's Trilemma a Christian affair not of their concern, while others object to its content considered incompatible with the Islamic views concerning the person of Jesus Christ.
\end{abstract}

Keywords: C.S. Lewis, trilemma, Jesus Christ, Islamic Tradition, Qur'an

\section{Introduction}

Considered one of the most influential Christian authors of the past century, C.S. Lewis built a personal theological system starting from the premise that there is a natural law which human beings - necessarily submitted to its influencesmust unconditionally accept. Thus, in his opinion, God must exist in His Trinitarian nature as Father, Son and Holy Spirit where the relationship between the Father and Son is the source of divine Love which acts through the Holy Spirit.

As a conservative apologist, C.S. Lewis made of the person and the nature of Jesus Christ the central themes of his life and work. But beyond his apologetic works about Christ and the Christian faith such as Miracles, The 
Problem of Pain, Abolition of Man and Mere Christianity and even beyond The Chronicles of Narnia, whose religious symbolism was acknowledged by the author himself (Clayton, p. 126), C.S. Lewis polarized the religious and nonreligious world with his famous Trilemma expressing his opinion on the nature and identity of Christ.

I am trying to prevent anyone saying the really foolish thing that people often say about Him: I'm ready to accept Jesus as a great moral teacher, but I don't accept His claim to be God. That is the one thing we must not say. A man who was merely a man and said the sort of things Jesus said would not be a great moral teacher. He would either be a lunatic - on the level with the man who says he is a poached egg-or else he would be the Devil of Hell. You must make your choice. Either this man was, and is, the Son of God: or else a madman or something worse. You can shut him up for a fool, you can spit at him and kill him as a demon; or you can fall at his feet and call him Lord and God. But let us not come with any patronising nonsense about his being a great human teacher. He has not left that open to us. He did not intend to. We are faced, then, with a frightening alternative. This man we are talking about either was (and is) just what He said or else a lunatic, or something worse. I have to accept the view that He was and is God. (Lewis, pp. 55-56)

Commonly rephrased as “Mad, Bad, or God”, Lewis's trilemma reminds the lemma concerning God attributed to Epicurus (qtd. in Lactantius, p. 494):

God (he says) either wants to remove evil and cannot, or can but doesn't want to: either he doesn't want to and cannot or he wants to and can. If he wants to and cannot, he is weak, but such a thing is not valid for God. If he can, but doesn't want to, he is cruel, which too is not in God's nature. If he does not want nor he can, he is cruel and weak, so he is not God. If he wants to and can as God should do, where do then bad things come from? Or why does he not remove them? ${ }^{1}$

That was transformed into a trilemma and continued by David Hume (p. 261) as follows: "Is He willing to prevent evil, but not able? then is He impotent. Is He able, but not willing? then is He malevolent. Is He both willing and able? whence then is evil?”

Even if the ideas expressed by Lewis's trilemma are not completely new, they managed to stir various degrees of interest not only within the Western society where religion as a whole is a constant matter of contradiction

\footnotetext{
${ }^{1}$ Deus (inquit) aut uult tollere mala, et non potest: aut potest, et no uult: aut neq; uult, neq; potest: aut et uult, et potest. Si uult et no potest, imbecillis est, quod in deum non cadit. Si potest, et non uult, inuidus, quod aeque alienu à deo. Si neq; uult, neq; potest, et inuidus, et imbecillis est, ideoq; neq; deus. Si uult, et potest, quod folum deo conuenit, unde ergo funt mala? Aut cur illa non tollit?
} 
and debate, but also-as we will show below-in a society, the Islamic one, where God and the content of His message cannot be the subject of any interpretation beyond those already accepted.

\section{A "Stone of Stumbling"}

Lewis's trilemma, which is a logical argumentation based more on his personal faith and beliefs than on a scientific approach to the Gospels, proved to be a "stone of stumbling" for many. For example, N. T. Wright (p. 98), the bishop of Durham, manifested his scepticism about Jesus Christ's claims of Divinity advanced by C.S. Lewis. He didn't oppose the trilemma in itself, which he thought to be perfectly logical, but raised some objections against Lewis's arguments, considering them rather simplistic even if correct.

Atheists too, as expected, argued against Lewis's trilemma, which they regarded as incomplete as, in their opinion, there was at least another element that should have been taken into account: that of the scientifically proven inaccuracy of the Gospels and the possible legendary/mythical dimension of Jesus Christ. As such, they opined that Lewis's trilemma was inaccurate as its author failed to take into consideration every possibility.

The "new atheist" Richard Dawkins (p. 92) suggested that if Jesus really had claimed to be Divine, which he doubted, C.S. Lewis's trilemma should have been transformed into a tetralemma, as Jesus could have been an honest liar. In other words, he might have been convinced of his Divinity even if Divinity was not present in him:

The historical evidence that Jesus claimed any sort of divine status is minimal. But even if that evidence were good, the trilemma on offer would be ludicrously inadequate. A fourth possibility, almost too obvious to need mentioning, is that Jesus was honestly mistaken. Plenty of people are. In any case, as I said, there is no good historical evidence that he ever thought he was divine.

Moreover, he accused C.S. Lewis of favouring a single possibility to the detriment of others implicitly (and incorrectly) rejected as false. In the same line of thought John Beversluis, one of the fiercest opponents of Lewis's religious ideas, wrote:

all (...) arguments are open to other objections. One of the most fundamental is that they all uncritically assume that the synoptic Gospels are historically reliable sources that accurately report what Jesus said-narratives that preserve his very words (or a very close approximation) rather than narratives that incorporate later recollections, interpolations, embellishments, fictionalizations, and ascriptions of deity. (p. 116) 
Commenting on the so-called Trilemma, philosopher-theologian John Hick says that those who endorse Lewis's claim that "someone claiming to be God must be either mad, bad, or God... continue to be unacquainted with modern biblical study," which does not uncritically assume that the synoptic Gospels are accurate reports of what Jesus said. (p. 117)

We can now dispose of the Lunatic or Fiend Dilemma once and for all. Since the proposition 'It is not impossible for someone to mistakenly claim to be God, and also be a great moral teacher' is false, it follows that... the Lord, Lunatic, or Fiend Trilemma is also blocked.... (p. 135)

Defending his positions expressed in the trilemma, Lewis wrote in "What are we to make of Christ?” (Dorsett, p. 331):

Now, as a literary historian, I am perfectly convinced that whatever else the Gospels are they are not legends. I have read a great deal of legend and I am quite clear that they are not the same sort of thing. They are not artistic enough to be legends. From an imaginative point of view they Ire clumsy, they don't work up to things properly. Most of the life of Jesus is totally unknown to us, as is the life of anyone else who lived at that time, and no people building up a legend would allow that to be so. Apart from bits of the Platonic dialogues, there are no conversations that I know of in ancient literature like the Fourth Gospel.

Beyond all controversies, C.S. Lewis's trilemma remains a logical argumentation based on a foundation that cannot be fully proved, nor fully denied $^{2}$, which transforms this kind of debates in an endless discussion similar to that concerning the gender of angels ${ }^{3}$.

\section{Systemic Incompatibilities}

While for Christians and atheists C.S. Lewis's trilemma is still a matter of rather harsh debate, for Muslims it represents a matter of much lesser importance. Some of those acquainted with C.S. Lewis's ideas approached it with caution for two reasons:

\footnotetext{
${ }^{2}$ There is no direct evidence in the Gospels that Jesus claimed to be God. That does not mean that his words cannot be understood in this respect (see John 10: 30; 10: 33; 8: 58 and the many instances in the Gospels which more or less directly attest His Divine Nature). Besides we should keep in mind that Christianity was intended from its very beginning to be a religion based on faith, not on scientific evidence.

${ }^{3}$ It seems that the byzantine theologians where so absorbed by their dispute regarding the gender of angels that they didn't pay any attention to the Ottomans who were about to conquer Constantinople in 1453.
} 
I. Because every fact or aspect related to the person and nature of Jesus Christ cannot be interpreted, as Christ is a prominent character in the Qur'an, being mentioned in many chapters (suras) ${ }^{4}$ :

1) as Jesus: $2: 136 ; 3: 45-56,59,84 ; 4: 163,172 ; 5: 110-118 ; 6: 85 ; 19:$ 22-23; 23: 50; 42: 13; 43: 57-64; 57: 27; 61: 6-14.

2) who demands to be listened to: 3: 50; $43: 63$.

3) miraculously conceived: 21: 91; 66: 12 .

4) as Christ (Messiah): 3: 45; 4: 171-172; 5: 17, 72, 75; 9: 30-31;

5) as the Word of God: 3: 39, 45; 4: 171;

6) as Jesus, son of Mary: 2: 87, 253; 3: 45; 4: 157, 171; 5: 46, 78, 110, 112, 114, 116; 19: 34; 23: 50; 33: 7; 43: 57; 57: 27; 61: 6, 14

7) who is not God: 5: 17-72; 9: 31; 4: 171; 9: 30; 19: 34-35.

8) who did not die: 4: 157-159;

9) who reinforce the previous revelations: $3: 50$; 5: 46; 61: 6;

10) accused of witchcraft: 5: 110; 61: 6.

11) who creates a bird: 3: 49; 5: 110 ;

12) who cures and brings people back to life: $3: 49$; 5: 110 ;

13) who brings a meal from Heaven;

14) miraculously born: 19: 2222-26.

15) who predicts the arrival of prophet Muhammad 61: 6 ;

16) as prophet: $3: 49,53 ; 4: 157,171 ; 5: 75,111 ; 61: 6$.

17) as servant of God: 19: 30; 43: 59.

18) who knows the hour of Judgement: 43: 61; 4: 159.

19) who speaks immediately after his birth: 5: 110; 19: 29-33.

Moreover, the entire chapter 19 of the Qur'an is dedicated to the events concerning Virgin Mary and the birth of Jesus - this is a central place taking into account that in Islamic numerology number 19 is considered equal to number 1 , which symbolizes the oneness of God, the core of the doctrine of tawhid ${ }^{5}$.

Besides the Qur'an, Jesus Christ is mentioned with the same prominence in the Sahih Bukhari, Sahih Muslim and Sunnan Abu Dawud, three of the six major hadith collections of the Sunni Islam:

Narrated Abu Hurairah: God's messenger said, 'by Him (God) in Whose Hands my soul is, surely the son of Maryam (Mary), 'Iesa (Jesus) will shortly descend amongst you people (Muslims) and will judge mankind justly by the Law of the Qur' an (as a just ruler) and will break the cross and kill the pigs and abolish the Jizya tax taken from the non-Muslims, who are under the protection of the Muslim government. This Jizya tax will not be accepted by 'Iesa (Jesus) peace

\footnotetext{
${ }^{4}$ Jesus Christ is mentioned in the Qur'an more than prophet Muhammad.

${ }^{5}$ The monotheistic doctrine of Islam according to which there is a single and indivisible God.
} 
be upon him. Then there will be abundance of money and nobody will accept charitable gifts”. (Al-Bukhari 3: 235-36).

The Messenger of God said: 'I am the closest of the people to Jesus son of Mary, in this world and in the Hereafter.' They said: 'How is that, O, Messenger of God?' He said: 'The Prophets are brothers; their mothers are different, but their religion is one, and there is no Prophet between us. (Muslim 6: 212).

It was narrated from Abu Hurairah that the Prophet said: "There is no Prophet between myself and him' - meaning 'Eisa (Jesus). He will descend and when you see him you should recognize him, a man of medium height with a reddish complexion, wearing two garments which have light yellow in them, with his head looking as if it is dripping although it will not be wet. He will fight the people for the cause of Islam, and he will break the cross and kill the pigs, and he will abolish the Jizyah. (Abu Dawud 4: 528-29),

II. Because, taking into account the Qur'anic statements about the revelations previously "descended" 6 upon man, Muslims generally regard the other monotheist Scriptures with deference and prefer not to comment on or interpret them in any way.

Thus, for many Muslim scholars C.S. Lewis's trilemma is a Christian affair. Those few who tried to express a point of view hastened to consider it as false, arguing that there are more then three hypotheses that should be considered.

In this respect, Bassam Zawadi (Call-to-monotheism.com) opined in a rather recent article concerning C.S. Lewis's trilemma that:

there are at least two other possible alternatives: 1) Jesus' words are not to be understood as him claiming to be God, therefore making the position of Muslim apologists and Unitarian Christians who argue that Jesus did not claim to be divine to be a possibility and 2) Even if the New Testament does clearly show

\footnotetext{
6 “And we caused Jesus, son of Mary, to follow in their footsteps confirming that which was (revealed) before him, and We bestowed on him the Gospel wherein is guidance and a light, confirming that which was (revealed) before it in the Torah a guidance and an admonition unto those who ward off (evil)./ Let the People of the Gospel judge by that which God hath revealed therein. Whoso judgeth not by that which God hath revealed; such are evil livers./ And unto thee have We revealed the Scripture with the truth, confirming whatever Scripture was before it, and a watcher over it. So judge between them by that which God hath revealed, and follow not their desires away from the truth, which hath come unto thee. For each We have appointed a divine law and a traced out way. Had God willed He could have made you one community. But that He may try you by that which He hath given you (He hath made you as ye are). So vie one with another in good works. Unto God ye will all return, and He will then inform you of that wherein ye differ.” (The Qur’an, 5: 46-48)
} 
that Jesus claimed to be God, it's possible that these words are falsely attributed to Jesus.

In conclusion, Christians who keep posing this argument need to start being a little bit more open minded and realize that there are other alternatives that they must engage with. To keep shoving this logically fallacious trilemma down the throats of people will do nothing but push them further away from them and create barriers to having a serious intellectual dialogue surrounding the topic of the historical Jesus.

This kind of speculative arguments are based on the Qur'an where Christ's Divine Nature is rejected either directly:

They surely disbelieve who say: Lo! God is the Messiah, son of Mary. The Messiah (himself) said: O, Children of Israel, worship God, my Lord and your Lord. Lo! Who so ascribeth partners unto God, for him God hath forbidden Paradise. His abode is the Fire. For evildoers there will be no helpers. (5: 72)

It befitteth not (the Majesty of) God that He should take unto Himself a son. Glory be to Him! When He decreeth a thing, He sayth unto it only: Be! And it is. (19: 35$)$

or indirectly:

O, People of the Scripture! Do not exaggerate in your religion nor utter aught concerning God save the truth. The Messiah, Jesus son of Mary, was only a messenger of God, and His word which He conveyed unto Mary, and a spirit from Him. So believe in God and His messengers, and say not «Three». Cease! (it is) better for you! God is only One God. Far is it removed from His transcendent majesty that he should have a son. His is all that is in the heavens and all that is in the earth. And God is sufficient as Defender. (4: 171)

\section{Conclusions}

In the light of the above-mentioned arguments, for the rather few Muslim scholars who approach C.S. Lewis's trilemma, Jesus was neither God or mad or bad, and nor was he a moral teacher. He was a messenger of God, a prophet ${ }^{7}$

\footnotetext{
7 "The Messiah, son of Mary, was no other than a messenger, messengers (the like of whom) had passed away before him. And his mother was a saintly woman. And they both used to eat (earthly) food. See how we make the revelations clear for them, and see how they are turned away!” (5: 75)

"And when Jesus son of Mary said: O, Children of Israel! Lo! I am the messenger of God unto you, confirming that which was (revealed) before me in the Torah, and bringing good tidings of a messenger who cometh after me, whose name is the Praised
} 
whose teachings or claims were misunderstood or distorted by his followers. Even if the Gospels transmit some statements allegedly made by him concerning his Divine Nature, these statements are to be considered inferior to those present in the Qur'an about the same matter, because the Gospels are considered only inspired scriptures while the Qur' an is considered a Revelation.

As He never claimed to be God, such a claim being seen as an error of the early Church who misunderstood Jesus, the trilemma, although logically correct, is based on incorrect premises, taking into account that the hypotheses advanced by C.S. Lewis are wrong according to the Qur'an.

Understanding it from a strictly Islamic point of view, the trilemma doesn't exist, as no argument provided by Lewis stands, not even the reason expressed by the British author as basis of his further argumentation: "I am trying to prevent anyone saying the really foolish thing that people often say about Him: I'm ready to accept Jesus as a great moral teacher, but I don't accept His claim to be God.” (see above, 55), as no Muslim would say that Christ was a moral teacher or God.

Detailing the trilemma elements, a Muslim wouldn't consider Jesus to be mad or bad because:

a) according to the Qur'an, he was the Word of $\operatorname{God}^{8}$, the Messiah, "a leader of the Muslims" (Al-Bukhari 3: 236) that will again return to Earth at the end of times, along with or immediately after the Mahdi ${ }^{9}$, and they will defeat the "false Messiah", the Antichrist (Ibn Khaldun 2: 156).

b) he did and said what he did and said not according to His will which could qualify Him as mad or bad but because He was predestined to do so.

c) Jesus was not the Son of God or God because the Qur'an expressly states that he was neither God, nor the Son of God.

C.S. Lewis's trilemma and argumentation concerning the identity of Jesus Christ could have been acceptable for the Muslims if Lewis had referred to Jesus as "the word of God" ${ }^{10}$ in the terms of St. John's Gospel, but this was not the purpose of the British author.

One. Yet when be hath come unto them with clear proofs, they say: This is mere magic" (61: 6)

8 "And the angels called to him as he stood praying in the sanctuary: God giveth thee glad tidings of (a son whose name is) John, who cometh (to confirm) a word from God, lordly, chaste, a Prophet of the righteous" (3: 39). "(And remember) when the angels said: O, Mary! God giveth thee glad tidings of a word from Him, whose name is the Messiah , Jesus, son of Mary, illustrious in the world and the Hereafter, and one of those brought near (unto God)" (3: 45).

${ }^{9}$ The Saviour of the Muslims mentioned in several Traditions (hadith).

10 "And the Word was made flesh, and dwelt among us, (and we beheld his glory, the glory as of the only begotten of the Father), full of grace and truth” (John 1: 14). The 


\section{Works Cited}

Lewis, Clive Staples. Mere Christianity. New York: Macmillan, 1952. Print.

\section{$* * *$}

Abu Dawud Sulayman bin Ash'ath, Hafiz. Sunan abu Dawud. Transl. Nasiruddin alKhattab. Riyadh: Darussalam, 2008. Print.

Al-Bukhari. Sahih Al-Bukhari. Transl. Dr. Muhammad Muhsin Khan. Riyadh: Darussalam, 1997. Print.

“Bassam Zawadi.” Examining C.S. Lewis' Trilemma. Call to Monotheism. General Articles on Christianity, 2014. Web.April 2015.

Beversluis, John. C.S. Lewis and the Search for Rational Religion. Revised and Updated. Amherst (NY): Prometheus Books, 2007. Print.

Clayton, Aaron. "The Lion, the Witch, and the Wii: Lewis's Theology în the Narnia Video Game”. C.S. Lewis, The Chronicles of Narnia. Eds. Michelle Ann Abate and Lance Weldy. Basingstoke: Palgrave Macmillan, 2012. 126-141. Print.

Dawkins, Richard. The God Delusion. London: Bantam Press, 2006. Print.

Dorsett, Lyle W., ed. The Essential C.S. Lewis. New York: Touchstone, 1996. Print.

Hume, David. Writings on Religion. La Salle (IL): Open Court, 1992. Print.

Ibn Khaldun. The Muqaddimah: An Introduction to History. Transl. Franz Rosenthal. Princeton: Princeton University Press, 1967. Print.

Lactantius, Lucius Caecilius Firmianus. Divinae institutiones (libri VII). Antuerpiae (Antwerpen): Ioan Graphei, 1532. Print.

Muslim bin al-Hajjaj, Abul Hussain. Sahih Muslim. Transl. Nasiruddin al-Khattab. Riyadh: Darussalam, 2007. Print.

The Holy Bible containing the Old and New Testaments. Oxford: Oxford University Press, 1953. Print.

The Noble Qur'an. English Translation: Marmaduke Pikthall. London: Islamadoft Solutions, 2000. DVD.

Wright, N. T. The Challenge of Jesus: Rediscovering who Jesus was and is. Downers Grove (IL): Intervarsity Press, 1999. Print.

Christian Tămaș is a Romanian Arabist, writer and translator. He holds a BA in Arabic Language and Literature from the University of Bucharest as well as a MA and a PhD in philosophy from the "Alexandru Ioan Cuza" University of Iaşi. His work includes more than one hundred published books, original and translations from and into eight foreign languages (Arabic, French, Italian, Spanish, Catalan, Portuguese, Irish and English). He authored monographs, studies and essays on Islam and on the philosophy of religion characterised by multidisciplinary approaches, among which: Crize contemporane: disolutia sacrului (2003) - Contemporary Crises: The Dissolution of Sacred; Communication Strategies in the Qur'an (2007 - Romanian version and 2011 -

sufis seem influenced by St. John's words as for them Jesus was born of Mary through the breath of the Holy Spirit, without having a physical father. 
English version); Modelul medinian și islamul global (2014) - The Medinan model and global Islam; Umanism şi alteritate în islam (2015) - Humanism and Otherness in Islam; 'El. Avatarurile unui articol hotărât (2012) -'El. The avatars of a definite article. He is a member of the Centre for Arab Studies of the University of Bucharest with whose Department of Arabic he currently collaborates.

Email: christiantamas@yahoo.co.uk 